\title{
RADICAI TPACIPR
}

A SOCIALIST, FEMINIST, AND ANTI-RACIST JOURNAL ON THE THEORY AND PRACTICE OF TEACHING

\section{News for Educational Workers}

by Leonard Vogt

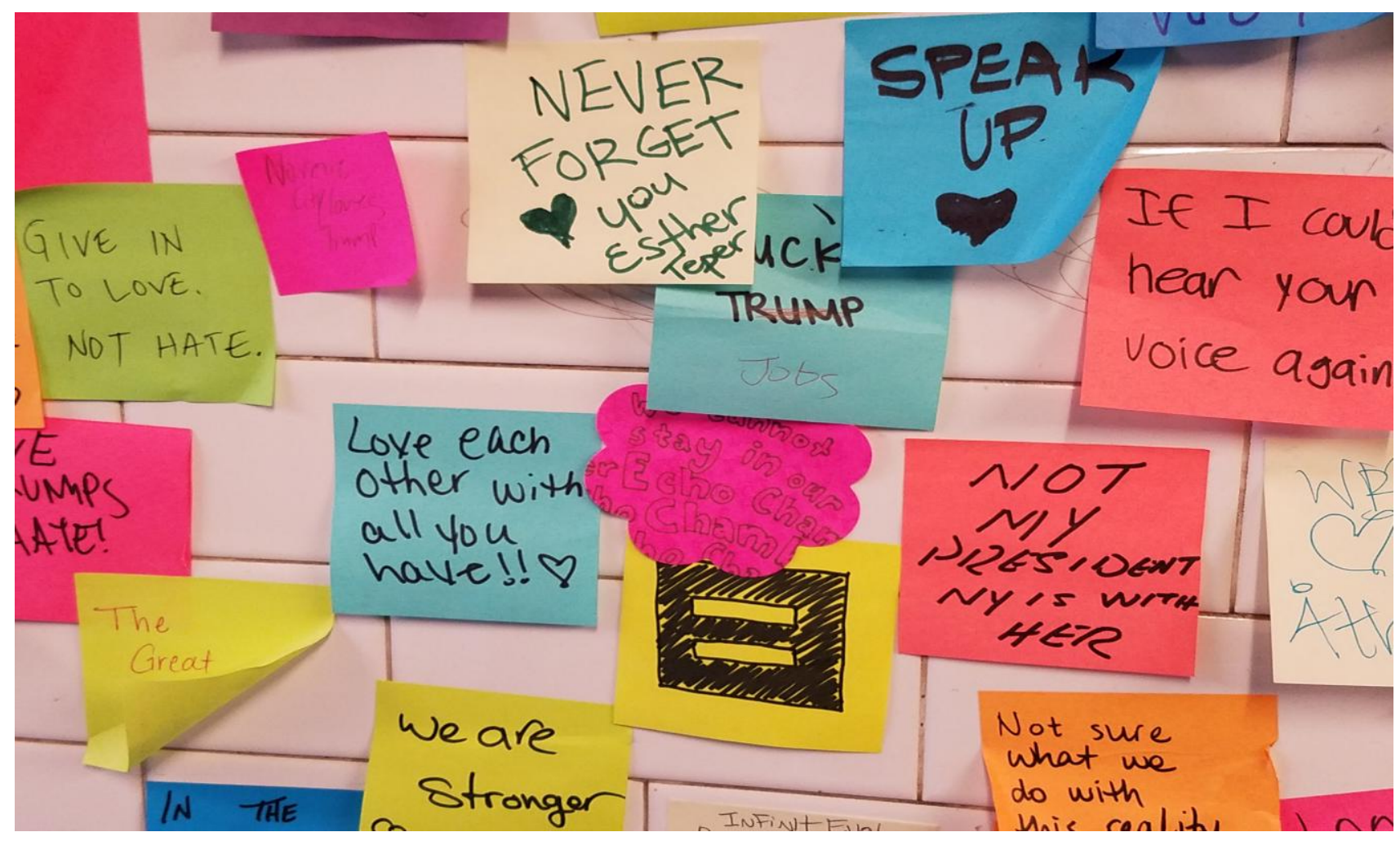

ANTI-TRUMP POST-ITS SUBWAY ART BY MATTHEW CHAVEZ UNION SQUARE STATION, NEW YORK CITY (PHOTO: LENORE BEAKY) 
News for Educational Workers has been a featured column of Radical Teacher almost since the journal's conception. With this issue of the journal, however, news items of interest to progressive and radical educators will be posted on the new Radical Teacher blog at http://www. radicalteacher.net/

Other less timely resources, such as books, film, magazines, and journal will continue to be featured in our newer, abbreviated News for Educational Workers column which will continue to be published with each of our forthcoming online issues.

\section{Books}

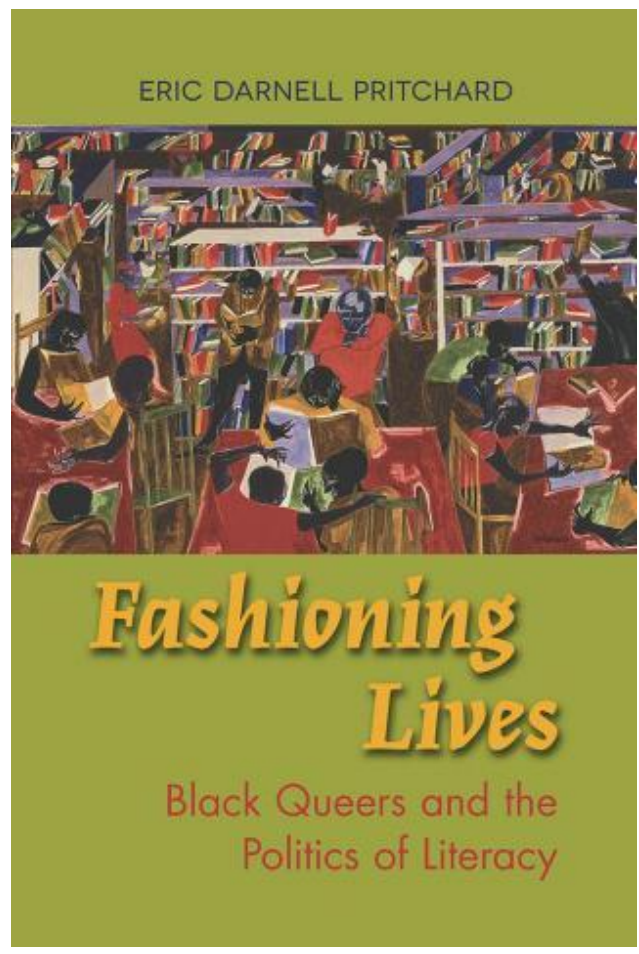

Fashioning Lives analyzes the life stories of sixty Black lesbian, gay, bisexual, transgender, and queer (LGBTQ) people along with archival documents, literature, and film. Doing so, the book provides a theoretical framework for studying the literacy work of Black LGBTQ people, who do not fit into the traditional categories imposed on their language practices and identities. Examining the myriad ways literacy is used to inflict harm, the book discusses how these harmful events prompt Black LGBTQ people to ensure their own survival by repurposing literacy through literacy performances fueled by accountability to self and communal love towards social and political change, a process I call "restorative literacies." The chapters highlight restorative literacies in literacy institutions (e.g., libraries, schools), historical records repositories, religious and spiritual spaces, parties, community events, activist organizations, and digital spheres.

To request a review copy, schedule an author for an interview or signing, or obtain information about course adoption, contact siupresspublicity@siu.edu | 618-4536634

For rights and permissions inquiries, contact rights@siu.edu. 


\section{Film}

\section{Bullfrog films presents three new videos:}

The Louisiana Gulf Coast has been battered by the worst of oil-and-gas industry activity and climate change: Hurricane Katrina, Deepwater Horizon, and now a rapidly eroding coastline. Yet the people, including those most affected, are standing up and fighting back to protect their wetlands, coastline and livelihoods, while looking to develop systems to address rising waters in After the Spill.

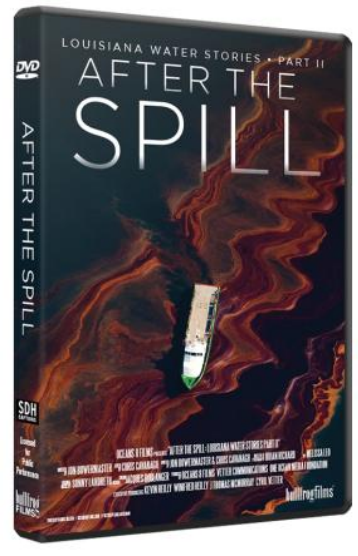

Disturbing the Peaceis story of the human potential unleashed when we stop participating in a story that no longer serves us and, with the power of our convictions, take action to create new possibilities. The film follows former enemy combatants - Israeli soldiers and Palestinian fighters - who have joined together to challenge the status quo and say "enough." When someone is willing to disturb the status quo and stand for the dream of a free and secure world, who will stand with them?

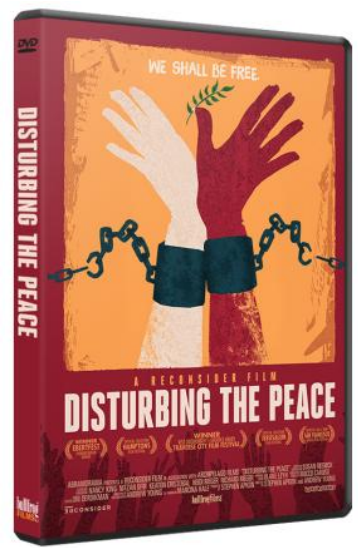

In 2012, California amended its "Three Strikes" law one of the harshest criminal sentencing policies in the country. The Return examines this through the eyes of prisoners suddenly freed, families turned upside down, reentry providers helping navigate complex transitions, and attorneys and judges wrestling with an untested law. The film gets to the heart of the current issue of mass incarceration in our nation and highlights the need for attention to equality in justice.

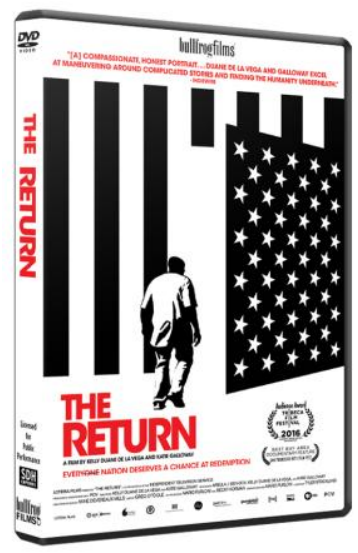

See http://www.bullfrogcommunities.comfor a complete list of all Bullfrog titles. If you have any questions, feel free to contact info@bullfrogcommunities.com.

\section{Journals and Magazines}

Works \& Days and Cultural Logic proudly announce the publication of their special issue called Scholasticism: Reflections on Transforming Praxis in and Beyond the Classroom (edited by Joseph Ramsey), a 500-page volume representing the work of 43 contributors, 21 essays, 3 interviews, poetry, and topics ranging from classroom pedagogies, labor struggles, the contradictions of online education and internet activisim, to critiques of the neoliberal university. To order a copy, send your email address to David Downing at downing@iup.edu. The cost is $\$ 10$ for this 500 page issue. 


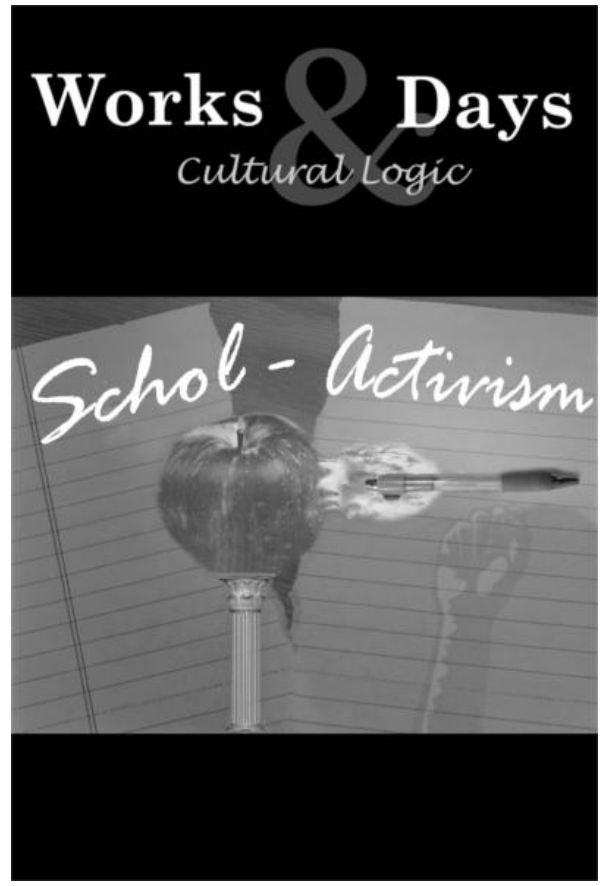

The Institute for Critical Education Studies announces that Workplace: A Journal for Academic Labor published its latest issue on the theme of "Marx, Engels and the Critique of Academic Labor" (edited by Karen Lynn Gregory and Joss Winn), which can be accessed at http://ices.library.ubc.ca/index.php/workplace.

\section{rethinking schools}

Philadelphia: Students on the Walls

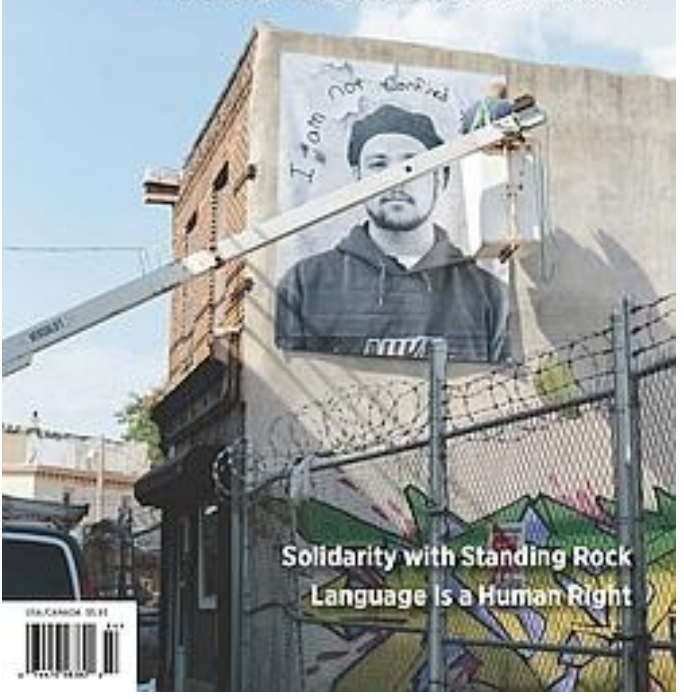

The current issue of Rethinking Schools (Winter201617 Vol. 31. No. 2) has a cover story about creating student identity on the walls of Philadelphia, feature articles on language as a human right and teaching the Tluskegee syphilis experiments, and editorials on teaching about solidarity with Standing Rock and critiquing Betsy DeVos, Donald Trump's nominee for U. S. secretary of education. To call or email, see below:

Business office:

1001 E. Keefe Avenue,

Milwaukee, WI 53212

- Phone: (414) 964-9646

- Fax: (414) 964-7220

- Email: office@rethinkingschools.org

\section{Orders:}

PO Box 2222

82 Winter Sport Ln,

Williston, VT 05495

- $\quad$ Phone (US \& Canada): (800) 669-4192

- $\quad$ Phone (International): (802) 862-0095 ext. 565

- Fax: (802) 864-7626

- Email: rts.orders@aidcvt.com

\section{(cc) EY-NC-ND}

ULIS D-Sorle

\section{This work is licensed under a Creative Commons Attribution-Noncommercial-No Derivative Works 3.0 United States License.}

This journal is published by the University Library System of the University of Pittsburgh as part of its D-Scribe Digital Publishing Program, and is cosponsored by the University of Pittsburgh Press.

\section{RADICAL TEACHER}

